science is crucial to economic recovery, he adds.

Young scientists are the least protected by existing labour laws and so will feel the brunt of the job cuts, says Irina Yehorchenko, a research fellow at the NASU's Institute of Mathematics in Kiev. She and some of her colleagues launched a petition in December calling on the country's president, Petro Poroshenko, to save Ukrainian science.

\section{YOUTHFUL POTENTIAL}

"I, for one, might be able to find a postdoc position abroad," says Oleksandr Skorokhod, a cell biologist at the NASU Institute of Molecular Biology and Genetics in Kiev who is chair of the academy's Council of Young Scientists. "But I'd much rather stay and try to change the bad state of affairs in my country."
Ukrainian science has struggled to recover from Russia's annexation of the Crimea peninsula in 2014. General consensus in the international community is that Crimea is still part of the Ukraine - the United Nations General Assembly declared invalid a March 2014 referendum in which voters in Crimea approved the peninsula's secession from Ukraine.

But all 22 Crimean institutes formerly run by the NASU are now under Russian control, and only a few of their 1,320 staff members have relocated to Ukraine-controlled territory. The academy lost access to its only research ship, the RV Professor Vodianytsky, three astronomical observatories in Nauchny, Katsiveli and Yevpatoria and the 204-year-old Nikitsky Botanical Garden near Yalta, on the Black Sea shore.

The Ukrainian government, moreover, expects scientists in Ukraine to cut all ties with colleagues who stayed on the peninsula, says Hrynevych, because any collaboration would be viewed as legitimizing the Russian occupation.

The armed conflict with pro-Russian militants in eastern Ukraine is also causing problems for scientists, especially in the country's Donbas region. Some 12,000 scientists and university lecturers there - about $60 \%$ of the former staff of 26 research institutes and universities in the province - have moved to safe institutions in Kiev and elsewhere. But many evacuating scientists left behind equipment or lost irreplaceable research material. Marine, environmental and climate studies in the Black Sea region, mining-related geology and a variety of archaeological and historical research have all been hit hard, says Zagorodny.

PUBLIC HEALTH

\title{
Spectre of Ebola haunts Zika response
}

\section{Agencies rush to show that outbreak tactics have improved.}

\section{BY ERIKA CHECK HAYDEN}

$\mathrm{P}$ ublic-health workers are still struggling to stamp out the Ebola epidemic in West Africa. But the lessons learned from that outbreak - which exposed major flaws in the global public-health system - are shaping the escalating international response to the spread of Zika virus in the Americas.

"Ebola is the gorilla in the room," says Lawrence Gostin, a health-law and policy specialist at Georgetown University in Washington DC. "It's driving everything."

$\mathrm{He}$ and others say that governments and international public-health agencies seem determined not to repeat the main mistake that they made with Ebola: waiting for much too long to respond to a brewing outbreak. The delay allowed Ebola to grow so out of control in West Africa that the epidemic there persists after more than 2 years and 11,000 deaths.

By contrast, the global health community has moved aggressively against Zika, beginning with a declaration from the World Health Organization (WHO) on 1 February that the clusters of microcephaly and other neurological disorders that have appeared in Brazil coincident with outbreak of the virus, and previously in French Polynesia, constitute an international public-health emergency.

The WHO has never yet made such a declaration before knowing the cause of the condition of concern. The August 2014 declaration that Ebola was a public-health emergency came after the disease had been spreading in West Africa for 8 months and had killed 932 people. But although Zika has probably infected as many as 1 million people in the latest outbreak, the vast majority have recovered. And scientists have not proved a link between Zika and microcephaly, a condition in which infants are born with abnormally small heads and brains.

"The WHO has perhaps gotten out ahead of its usual position of gathering and verifying all the evidence before taking a clear position," says Adam Kamradt-Scott, a health-security specialist at the University of Sydney in Australia. "The WHO couldn't afford to be seen to be asleep at the wheel a second time."

Other authorities have taken similarly bold action. On 3 February, the US Centers for Disease Control and Prevention (CDC) moved its emergency-response operations centre to its highest activation level, jump-starting US government research into, and surveillance of, the Zika virus. On the same day, the United Kingdom announced the creation of a Zika research fund with an initial budget of up to $£ 1$ million (US\$1.4-million). And on 8 February, US President Barack Obama requested $\$ 1.8$ billion from lawmakers for Zika-response activities. (By comparison, Obama’s \$6.18-billion request for Ebola-response funding came 3 months after that virus was declared a global emergency.)

The ongoing mobilization against Zika is not an over-reaction, says Suerie Moon, a global-health researcher at the Harvard T. H. Chan School of Public Health in Boston, Massachusetts. Although Zika - unlike Ebola - is not usually fatal, it has the potential to cause suffering and social and economic havoc. "It's encouraging to see leadership and mobilization from WHO, CDC and other public-health institutions," Moon says. "It shows that some of the lessons from Ebola have been digested."

WHO director-general Margaret Chan has acknowledged the agency's failings on Ebola, citing "inadequacies and shortcomings in this organization's administrative, managerial and technical infrastructures" in a speech last year.

The Zika response also highlights persistent flaws of the global public-health system. Zika was first discovered in Africa in 1947, and caused a major outbreak in 2013 in the Pacific islands, but there is still no vaccine, treatment or common diagnostic test for the virus.

Kamradt-Scott wonders if the world would be tracking Zika's spread so closely if the virus had not emerged in Brazil, where hundreds of thousands of tourists are scheduled to attend the Olympic Games in August. "My own perception is that the international community hasn't responded particularly swiftly to Zika," he says.

Moon notes that although the WHO is trying to ensure that researchers in government, academia and industry share data on the outbreak, drug companies developing Zika vaccines have not publicly agreed to participate.

The WHO has long struggled to modulate its response to global-health crises, Gostin says. After it was criticized for reacting too strongly to the 2009 H1N1 influenza epidemic - declaring a full-scale pandemic, when the virus itself did not prove as deadly as was initially feared - it dialed back its response to the Ebola outbreak. Now the WHO is mounting an urgent response to Zika, in light of criticism of its reaction to Ebola. To Gostin, this inconsistency reinforces a perception that the WHO acts mainly on the basis of political, not medical, factors. "We need to stop fighting the last war," he says. 